\title{
China's Mushrooming Free Trade Agreements: New Zealand and China's Upgraded Free Trade Agreement
}

\author{
FARRUKH NAWAZ KAYANI \\ Department of Economics \\ College of Economics and Management \\ Al Qasimia University, Sharjah \\ United Arab Emirates.
}

Abstract: FTAs have mushroomed and proliferated at very fast pace in East Asia, especially after the Asian Financial Crisis (AFC) of 1997. The East Asian economies were very disappointed with the International

Monetary Fund's handling of the crisis. In particular, it provided some countries, like Thailand and Indonesia, with poor advice. After the AFC, countries like China, Japan, and South Korea signed FTAs with different countries around the world. The first East Asian FTA talks took place between Japan and South Korea in 1998. Like its neighbors, China also pursued FTAs with neighboring countries. The FTA between China and New Zealand was signed on the $7^{\text {th }}$ of April 2008 and was implemented on the $1^{\text {st }}$ of October 2008. As a result of this FTA, China has become New Zealand's largest trading partner; New Zealand's exports to China have quadrupled. As of June 2020, the trade between China and New Zealand exceeded NZ\$32 Billion. China and New Zealand signed an upgraded FTA on the $26^{\text {th }}$ of January 2021. The upgraded FTA includes rules relating to e-commerce, competition policy, government procurement, and environment and trade issues. The bilateral trade between China and New Zealand is complimentary rather than competitive; while China mainly exports manufactured products to New Zealand, New Zealand primarily exports agricultural products.

Key Words: China, New Zealand, Bilateral Trade, Free Trade Agreements, Foreign Direct Investment, Economic Integration.

Received: November 13, 2021. Revised: May 3, 2021. Accepted: May 12, 2021. Published: May 21, 2021.

\section{Introduction}

Globalization and internationalization mean that the world is like a global village; everything is now within reach using just one click. Trade volume is a prime indicator of a country's economic growth. Numerous countries around the world have entered into various trade agreements with other countries to expand the volume of trade between them and to enjoy the resources held by other countries. Free Trade Agreements (FTAs) are designed to reduce the trade restrictions between countries and promote the free flow of goods across national borders. FTAs represent formal and mutual agreements between the signing nations. However, the respective parties have proper mechanisms for controlling and processing trade related activities.

Why do governments prefer FTAs over multilateral agreements? One of the reasons for signing an FTA is that they are faster and easier to conclude. For example, Uruguay round under the General Agreement on Trade and Tariffs (GATT) took 8 years to complete, even though negotiations were only meant to last 4 years. FTAs are governed and administered under WTO rules, more specifically, GATT Article

XXIV (for goods) and Article V (for services). The WTO aims to integrate economies at a global level by motivating countries to adopt open and liberal trade policies.

In East Asia, FTAs mushroomed and proliferated at a tremendously fast pace, especially after the AFC in 1997. The East Asian economies were disappointed with the way the International Monetary Fund (IMF) handled the crisis, especially in relation to Thailand and Indonesia. After the AFC, countries like China, Japan, and South Korea began to sign FTAs with different countries around the globe. The first East Asian FTA talks 
took place between Japan and South Korea in 1998. China has been particularly active, establishing FTAs with different countries around the world, and in particular, with its East Asian neighbors.

FTAs facilitate greater trade openness using formal methods. This is achieved by abolishing cross-border barriers and coordinating various rules. The sale of goods and service trade across borders results in greater trade, industrialization, higher rates of employment, and greater economic growth. FTAs encourage greater trade and Foreign Direct Investment (FDI) among the member countries through the liberalization of goods and service trade. FTAs and FDI produce advancements in technologies, trade promotion, employment opportunities and economic growth.

The Chinese New Zealand FTA was signed on the $7^{\text {th }}$ of April, 2008, before being implemented on the $1^{\text {st }}$ of October, 2008. Since the FTA, New Zealand's exports to China have quadrupled. China has become New Zealand's largest trading partner. The bilateral trade between China and New Zealand is complimentary rather than competitive; While China mainly exports manufactured products to New Zealand, New Zealand primarily exports agricultural products to China.

Since its introduction in 2008, there have been significant changes in the business environment/business practices and the trade rules. As a result of these changes, both countries agreed in 2016 to upgrade and modernize the existing FTA. China and New Zealand signed an upgraded FTA on the $26^{\text {th }}$ of January 2021. The upgraded FTA includes new regulations on e-commerce, competition policy, government and procurement, and environment and trade issues. This study analyzes the upgraded China-New Zealand FTA.

The remainder of article is organized as follows. Section 2 discusses the role of FTAs under the WTO: they represent a stepping-stone towards the greater trade liberalization. Section 3 explains the different FTAs China is involved in and the rationale behind these FTAs. Section 4 examines the relationship between FTAs and FDI in relation to the current literature. Section 5 analyzes the upgraded China New Zealand
FTA which was signed in January 2021. The upgraded agreement represents a modernized version of the original FTA between China and New Zealand, rather than a replacement of the original one. Section 6 concludes the paper.

\section{Preferential Agreements as Stepping-Stones for Trade Liberalization}

Since the early 1990s, there has been much debate, particularly in economic circles, about whether FTAs promote, or hinder trade liberalization. This question has generated considerable controversy between the economists, resulting in two opposing perspectives. One group of economists see FTAs as a stepping-stone for further trade liberalization. The other group of economists regard FTAs as stumbling blocks; they believe that FTAs lead to protectionism.

FTAs operate under the WTO. FTAs exist and operate under the multilateral trading system. WTO rules governing FTAs include GATT Article XXIV on trade in goods, GATS Article $\mathrm{V}$ on trade in services and the Enabling Clause on South-South (preferential) agreements. FTAs are legally binding arrangements between two or more countries, in which the countries involved give preferential treatment in trade. They also remove trade protection measures for members of the agreement. Each member retains their own tariff structure in their trading with other countries [1]. FTAs strengthen the trade relations among partner countries and make it easier to build alliances for WTO reforms in areas of common interest [2]. FTAs play an important role in promoting the liberalization and expansion of trade and fostering development [3].

One view argues that FTAs promote liberalization, and that the expansion of FTAs will facilitate trade liberalization on a global scale [4]. During the Ministerial Meeting of the Doha round, most of the governments agreed that regional trade agreements play an important role in promoting trade liberalization and the expansion of trade. 
What is less known in discussions about FTAs is why countries prefer FTAs over multilateralism. This paper explores a few of the reasons this may be the case. FTAs help likeminded countries to reach an agreement quickly and easily. One of the reasons for signing FTAs is that they are faster and easier to conclude. The Uruguay round under the General Agreement on Trade and Tariffs (GATT) took eight years to complete even though it was meant to take four years. Furthermore, negotiations between two (or a few) countries are more cost-effective compared to negotiations conducted between the 160 WTO member countries. These examples demonstrate that FTAs would speed up the multilateral trade liberalization of the WTO.

The WTO came into being on the $1^{\text {st }}$ of January. 1995. It replaced the GATT after the completion of the Uruguay Round of Trade Talks (19861994). [5].

Table 1: GATT Trade Rounds (1947-1994)

\begin{tabular}{|c|c|c|c|}
\hline Year & Location & Key Discussion & $\begin{array}{l}\text { Participating } \\
\text { Countries }\end{array}$ \\
\hline 1947 & Switzerland & Tariffs & 23 \\
\hline 1949 & France & Tariffs & 13 \\
\hline 1951 & England & Tariffs & 38 \\
\hline 1956 & Switzerland & Tariffs & 26 \\
\hline & Switzerland & Tariffs & 26 \\
\hline 1964-1967 & Switzerland & $\begin{array}{l}\text { Tariffs and Antidumping } \\
\text { Measures }\end{array}$ & 62 \\
\hline 1973-1979 & Switzerland & \begin{tabular}{|l|} 
Tariffs, non-tariff measures \\
"framework" agreements
\end{tabular} & 102 \\
\hline 1986-1994 & Switzerland & \begin{tabular}{|l} 
Tariffs, non-tariff measures, rules, \\
services, intellectual property, \\
dispute $\quad$ settlement, textiles, \\
agriculture,
\end{tabular} & 123 \\
\hline
\end{tabular}

Source: [6]

\section{China's Blossoming Free Trade Agreements}

China is pursuing FTAs with the different countries around the world, for a variety of reasons [7]. China's primary aim is to gain a central position in the market which will mean it is not answerable to special safeguards. Secondly, by instituting FTAs, China is able to access and control some of the world's key resources such as copper in Chile, oil in GCC countries, iron ore and uranium in Australia. Thirdly, China hopes to strengthen its relationship with East Asian to influence the decision making in that region [8].

Besides regional agreements, China is also pursuing individual agreements, such as FTAs with Hong Kong and Macao. These individual agreements aim to normalize the relationship between Mainland China and these markets [9].

China's FTAs with the special administrative regions of Hong Kong and Macau established in 2004 are considered an "endowment" from 
China to Hong Kong and Macau. China's FTA with Chile (established in 2006) is both monetarily and strategically significant for China. China sees its FTA with Chile as a bridge between Asia and Latin America. Significantly, Chile is the biggest producer of copper; China is the biggest consumer of copper [10]. The China-Pakistan FTA was established in 2007. This FTA has increased the trade volume for both countries. Logically, Pakistan is a doorstep trading partner for China and trade ties with neighboring country like Pakistan are economical and cost efficient for China.

China also signed an FTA with New Zealand in 2008. It was the first FTA China signed with an industrialized economy. The 2008 FTA includes trade opportunities based on goods, services, and investments.

China also signed an FTA with Singapore in 2008. It represents a new milestone in the development of bilateral trade and economic relations and is exerting a positive influence upon East Asian's economic integration. The China-Peru FTA is the first comprehensive FTA that China has signed with a Latin America country and was established in 2009. It is a new landmark in the relations between China and Peru. This agreement further deepens the economic and trade relations between the two countries and demonstrates the two countries' goal to fight against protectionism.

The FTA between China and Costa Rica came into force in 2011. The signing of China and Costa Rica's FTA reveals the determination of the two countries in bolstering and strengthening their mutual relationship. Iceland was the first European country to negotiate and sign an FTA with China. Signed in 2014, this FTA has injected huge vitality to the long term economic and trade relations between China and Iceland. China also signed an FTA with Switzerland in 2014. It is one of the most comprehensive FTAs that China has signed with any country to date. It is also the first agreement that China has signed with any European country which is included in the top 20 leading economies of the world. This FTA further deepens China-EU trade and economic relations. China is Switzerland's third-largest trading partner after the EU and the US.

China signed FTAs with both South Korea and Australia in December 2015. These agreements further cement the bilateral relations, promote the free flow of goods, and create easier and fairer trade. The China-South Korea FTA is China's largest bilateral free trade deal in terms of trade volume. It covers 17 areas, including trade in goods and services, investment, trade rules, e-commerce, and government procurement.

The FTA between China and Maldives was signed on the $7^{\text {th }}$ December 2017. China and the Maldives are traditional friends, and this FTA brings new opportunities for the development of bilateral trade. The FTA between China and Georgia came into force on the $1^{\text {st }}$ January 2018. This FTA plays an important role in promoting trade and economic relations between China and the Eurasian economies. The FTA between China and Mauritius was signed on the $17^{\text {th }}$ of October 2019. It has elevated China-Africa economic and trade cooperation to new heights. China is currently negotiating FTAs with the GCC, Norway and Sri Lanka. The trilateral FTA between China-Japan-Korea is also currently under negotiation. China is interested in stronger ties with the GCC because the GCC is the biggest exporter of oil and China has strong growing demands for energy. In Northern Europe, Norway is an important trading partner with China. Norway supplies fertilizers, aquatic products, and oil to China. China is the main source of foreign investment in Sri Lanka. A China-Sri Lanka FTA would further deepen the economic and trade relations. 
Table 2: China's Free Trade Agreements

\begin{tabular}{|c|c|c|c|}
\hline Year & Trade Categories & Signing Countries & Details of the Agreements \\
\hline $2004 \& 2015$ & Goods and Services & $\begin{array}{l}\text { Mainland China and Hong } \\
\text { Kong Closer Economic } \\
\text { Partnership Arrangement }\end{array}$ & Free Trade Agreement on Goods and Services. \\
\hline $2004 \& 2015$ & Goods and Services & $\begin{array}{l}\text { Mainland China and Macao } \\
\text { Closer Economic Partnership } \\
\text { Arrangement }\end{array}$ & Free Trade Agreement on Goods and Services. \\
\hline $\begin{array}{l}2005,2007 \& \\
2009\end{array}$ & $\begin{array}{l}\text { Goods, Services, and } \\
\text { Investment }\end{array}$ & $\begin{array}{l}\text { Framework Agreement on } \\
\text { Comprehensive Economic } \\
\text { Co- operation between China } \\
\text { \& ASEAN }\end{array}$ & $\begin{array}{l}\text { Establishes the ASEAN-China Free Trade Area } \\
\text { (ACFTA). }\end{array}$ \\
\hline $2006 \& 2008$ & Goods and Services & China-Chile FTA & $\begin{array}{l}\text { China agreed to reduce tariffs on } 97 \% \text { of } \\
\text { Chilean exports. }\end{array}$ \\
\hline $2007 \& 2009$ & Goods and Services & China-Pakistan FTA & $\begin{array}{l}\text { China agreed to eliminate tariffs on } 35.5 \% \text { of } \\
\text { tariff lines within three years and reduce tariffs } \\
\text { on another } 48.5 \% \text { within five years. }\end{array}$ \\
\hline 2008 & $\begin{array}{l}\text { Goods, Services, and } \\
\text { Investment }\end{array}$ & China-New Zealand FTA & $\begin{array}{l}\text { China agreed to remove tariffs on } 96 \% \text { of New } \\
\text { Zealand exports by } 2019\end{array}$ \\
\hline 2008 & Goods and Services & China-Singapore FTA & $\begin{array}{l}\text { China agreed to remove tariffs on } 97.1 \% \text { of } \\
\text { Singapore's exports to China by } 2012 \text {. }\end{array}$ \\
\hline 2009 & $\begin{array}{l}\text { Goods, Services, and } \\
\text { Investment }\end{array}$ & China-Peru FTA & $\begin{array}{l}\text { China agreed to eliminate tariffs on } 90 \% \text { of all } \\
\text { trade items within } 16 \text { years. }\end{array}$ \\
\hline 2011 & Goods and Services & China-Costa Rica FTA & $\begin{array}{l}\text { China would eliminate tariffs on } 90 \% \text { of Costa } \\
\text { Rican goods. }\end{array}$ \\
\hline 2014 & $\begin{array}{l}\text { Goods, Services, and } \\
\text { Investment }\end{array}$ & China-Iceland FTA & $\begin{array}{l}\text { China would impose zero tariffs on } 96 \% \text { of } \\
\text { Icelandic products. }\end{array}$ \\
\hline 2014 & Goods and Services & China-Switzerland FTA & $\begin{array}{l}\text { China agreed to remove tariffs on } 84.2 \% \text { of } \\
\text { Swiss exports. }\end{array}$ \\
\hline 2015 & $\begin{array}{l}\text { Goods, Services, and } \\
\text { Investment }\end{array}$ & China-Australia FTA & $\begin{array}{l}\text { China would eliminate tariffs on } 85 \% \text { of } \\
\text { Australian exports. }\end{array}$ \\
\hline 2015 & $\begin{array}{l}\text { Goods, Services, and } \\
\text { Investment }\end{array}$ & China-South Korea FTA & $\begin{array}{l}\text { Both sides would eliminate tariffs by } 90 \% \text { over } \\
\text { next } 20 \text { years. }\end{array}$ \\
\hline 2017 & $\begin{array}{l}\text { Goods, Services, } \\
\text { Investment and } \\
\text { Economic \& Technical } \\
\text { Cooperation }\end{array}$ & China-Maldives FTA & $\begin{array}{l}\text { The agreed zero-tariff products and their } \\
\text { imports for both sides is appropriately } 96 \% \text {. }\end{array}$ \\
\hline 2018 & Goods and Services & China-Georgia FTA & $\begin{array}{l}\text { Georgia will impose zero tariffs on } 96.5 \% \text { of } \\
\text { China's products and China will impose zero } \\
\text { tariffs on } 93.9 \% \text { of Georgian products. }\end{array}$ \\
\hline 2019 & $\begin{array}{l}\text { Goods, Services, } \\
\text { Investment and } \\
\text { Economic Cooperation }\end{array}$ & China-Mauritius FTA & $\begin{array}{l}\text { China and Mauritius will eventually impose } \\
\text { zero tariffs; they are currently at } 96.3 \% \text { and } \\
94.2 \% \text { respectively. }\end{array}$ \\
\hline
\end{tabular}

Source: Chinese Ministry of Commerce. 


\section{Free Trade Agreements and Foreign Direct Investment}

FTAs provide a supportive environment for foreign investors as they help them to secure intellectual property rights, institutionalize their participation in the host economy, and assure them of the government's commitment to a liberal economic policy. Before examining the relationship between FTA and FDI, it is first necessary to understand the differences between horizontal and vertical FDI. When multinational firms produce products in various countries and sell them directly to the local market this is known as horizontal FDI. Horizontal FDI declines, due to reductions in the cost of goods, when an FTA is launched between trade partners. Vertical FDI refers to a situation where multinational firms are involved in various stages of production in different countries to take advantage of trading partners. Vertical FDI increases after signing an FTA with trade partners due to reductions in production and transportation costs. Theoretically, FTAs have a positive influence on vertical FDI and a negative impact on horizontal FDI.

In the case of Vietnam, [11] conducted a study to determine the impact or contribution of FTAs on inward FDIs. The study was executed over 20 countries, including 14 of Vietnam's FTAs partners and 6 non-FTA partners. The study used the gravity model to examine panel data obtained from 20 countries over the period of 1995-2014. The findings support earlier studies. The authors found a positive and significant relationship between FTAs and FDI. The study also noted the importance of other factors, including the banking crisis of 1997, the exchange rate of host country and WTO membership. Similarly, [12] analyzed the impact of Vietnam's FTAs upon FDI. They employed a gravity model to analyze panel data for the period of 1995 until 2011. The study involved 17 important trading and FDI partners (Australia, Belgium, Canada, China, France, Germany, Hong Kong, Japan, Malaysia, the Netherlands, the Philippines, Singapore, the Republic of Korea, Taiwan, Thailand, the United Kingdom, and the United States). The authors found that FTAs had a strong positive impact on inward FDI.
The impact of FTAs upon bilateral FDIs was studied by [13]. He used a Knowledge-Capital Model to analyze a sample of 30 OECD and 32 non-OECD countries. Data was collected for the period of 1982 to 2005 . He found that when both countries are developed countries, then FTAs have a negative impact upon FDI. However, if one country is developed and the other one is developing then FDAs have a positive impact. Similarly,[14] identified the empirical impact of FTAs on Korea's inward and outward FDI. They hypothesised that they would find a positive effect on outward FDI for developing countries and inward FDI effect for developed countries due to FTAs. They used Korean FDI and FTAs for the period of 2000 to 2010 . They proved the hypothesis correct and concluded that in general, FTAs encourage FDI in a friendly environment. [15] investigated the impact of Regional Trade Agreements (RTA) upon FDI by taking into consideration the market size of the countries. The sample was comprised of data from 71 developing countries from 1980-1999. The study found that countries with a large and educated labor force and stable financial institutions attracted a larger share of FDI, even at the expense of their RTA partners.

\section{China and New Zealand's Upgraded Free Trade Agreement}

China and New Zealand established an FTA in 2008. This FTA is designed to encourage greater trade and economic opportunities for both countries. This trade agreement is particularly fascinating as both countries have very different economies. While China has a large population, an abundant labor force, and low per capita income, New Zealand has a small population, a scarce labor force, and high per capita income. Both countries have different languages, different cultures and are geographically distant from one another [16]. Since the introduction of the FTA, New Zealand's exports to China have quadrupled. Similarly, China has become New Zealand's largest trading partner. As of June 2020, the two-way trade between China and New Zealand exceeded NZ\$32 billion. New Zealand's exports to China amounted to $\$ 19.4$ billion. China's exports to New Zealand amounted to 
$\$ 13$ billion. New Zealand primarily exported dairy products, meat products, wood products, cereal preparations, and fish.
China primarily exported electronics, machinery, clothing, furniture, plastics, toys, and games to New Zealand [17].

\section{Table 3: New Zealand's Trade with China}

New Zealand's trade with the People's Republic of China

Quarterly - NZ\$ million

Dec-19 Mar-20 Jun-20 Sep-20 Dec-20

\section{Total exports}

\begin{tabular}{|c|c|c|c|c|c|}
\hline Total & 6,033 & 4,528 & 4,695 & 3,799 & 5,614 \\
\hline Total goods & 5,252 & 3,788 & 4,195 & 3,397 & 5,246 \\
\hline Total services & 781 & 740 & 499 & 401 & 367 \\
\hline \multicolumn{6}{|c|}{ Top 5 goods exports for December 2020 quarter } \\
\hline Dairy & 2,450 & 1,277 & 1,208 & 848 & 2,268 \\
\hline Meat and edible offal & 1,004 & 768 & 940 & 463 & 787 \\
\hline Wood & 685 & 537 & 630 & 706 & 769 \\
\hline Cereal preparations & 185 & 266 & 267 & 214 & 365 \\
\hline Fish & 139 & 108 & 145 & 150 & 219 \\
\hline \multicolumn{6}{|c|}{ Top 5 services exports for December 2020 quarter } \\
\hline Travel & 699 & 668 & 445 & 354 & 317 \\
\hline Transportation & 58 & 52 & 34 & 26 & 28 \\
\hline Financial services & $\mathrm{C}$ & 6 & 6 & 6 & 7 \\
\hline Other business services & 7 & 6 & 4 & 5 & 4 \\
\hline Insurance and pension services & 2 & 1 & 5 & 2 & 3 \\
\hline \multicolumn{6}{|l|}{ Total imports } \\
\hline Total & 3,798 & 2,635 & 3,117 & 3,349 & 3,787 \\
\hline Total goods & 3,580 & 2,486 & 3,008 & 3,188 & 3,616 \\
\hline Total services & 218 & 150 & 109 & 161 & 171 \\
\hline
\end{tabular}


New Zealand's trade with the People's Republic of China

Quarterly - NZ\$ million

Dec-19 Mar-20 Jun-20 Sep-20 Dec-20

\section{Top 5 goods imports for December 2020 quarter}

\begin{tabular}{lccccc}
\hline Electrical machinery and equipment & 800 & 460 & 557 & 636 & 868 \\
\hline Machinery & 651 & 468 & 611 & 601 & 633 \\
\hline Furniture & 227 & 138 & 145 & 201 & 225 \\
\hline Plastics & 169 & 119 & 190 & 152 & 166 \\
\hline Toys and games & 134 & 52 & 65 & 115 & 153 \\
\hline
\end{tabular}

Top 5 services imports for December 2020 quarter

\begin{tabular}{lccccc}
\hline Transportation & 69 & 37 & 32 & 54 & 69 \\
\hline Travel & 79 & 68 & 33 & 50 & 51 \\
\hline Other business services & 50 & $\mathrm{C}$ & $\mathrm{C}$ & 42 & 36 \\
\hline Insurance and pension services & 2 & -- & 1 & 3 & 4 \\
\hline Charges for the use of intellectual property (NIE) & $\mathrm{C}$ & $\mathrm{C}$ & -- & -- & -- \\
Data may not sum total due to rounding & & & & & \\
C confidential & & & & & \\
.. data not available & & & & \\
-- data too small to express & & & & \\
\hline
\end{tabular}

Source: Statistics NZ

Since the establishment of diplomatic relations in 1972, China and New Zealand have a enjoyed good relationship The original FTA between China and New Zealand was signed on the $7^{\text {th }}$ of April 2008 and implemented on the $1^{\text {st }}$ of October 2008. While this FTA provided economic opportunities for both countries, over time, the trade rules and business practices have changed significantly. Thus, in 2016, both countries agreed to upgrade and modernize the existing FTA. China and New Zealand signed an updated FTA on the $26^{\text {th }}$ of January 2021. The upgraded FTA addresses issues like e-commerce, competitive policy, government procurement, environmental issues and trade concerns. Improvements in New Zealand's goods market, greater access to the Chinese market and the elimination of tariffs on New Zealand products such as wood and paper have enhanced the trade volume by NZ $\$ 35$ million. This FTA has established new channels for dialogue and policy cooperation with China. The upgraded

FTA has created a more secure and certain environment for New Zealand exports. 
The upgraded FTA includes Electronic Commerce. This inclusion increases the usage of E-Commerce by businesses and the consumers on both sides and has helped to transform the China-New Zealand trade relations. Paperless trading is encouraged and promoted via digital certificates and electronic authentication. Both countries have also agreed to protect important information relating to ecommerce using a proper legal framework.

Both parties have agreed to maintain the practice of no custom duties upon electronic transmissions and to promote the usage of ECommerce among small and medium enterprises as well.

One of the most important developments in upgraded FTA is the inclusion of a new chapter of competition policy. Both countries agreed to protect consumer welfare and to avoid deceptive practices in the trade of goods and services. The countries also agreed that cooperation between the competition law enforcement agencies will take place on a regular basis. Government procurement will also be carried out in a fairer and more transparent manner to prevent corruption. The chapter also includes a built-in agreement to enter market access negotiations with New Zealand once China completes its accession to the WTO Agreement on Government Procurement, or if it were to negotiate market access on government procurement with another country. The upgraded FTA includes a chapter about the Environment and Trade. It states that any trade must be environmentally friendly. A new committee will be formed to facilitate the dialogue needed for the effective implementation of this chapter.

The upgraded FTA has adjusted the chapter related to the movement of natural persons. It reallocates visas for Chinese professionals. While the original cap of 800 visas remains unchanged, there have been changes in the existing five categories. The visas for Chinese tour guides have increased from 100 to 200 visas, as has the number of Chinese language teachers (from 150 to 300 visas). The numbers in the other visa categories have decreased so as to maintain the overall cap of 800 [14].

\section{Conclusion}

The article is very timely as FTAs are currently being negotiated and renegotiated all over the world. Countries that have signed FTAs are experiencing great surges in exports and productivity. China is no longer the exception, as the country signs and implements dozens of FTAs with different countries. It has worked with multiple countries to encourage freer trade on a form basis. This has been achieved by abolishing cross-border barriers and coordinating various rules.

The China-New Zealand FTA, established in 2008, has increased trade and economic opportunities for both countries. The FTA between China and New Zealand is particularly interesting as both countries possess very different economies. Since the FTA came into effect, China has become New Zealand's largest trading partner. In June 2020, the trade between the two countries exceeded NZ\$32 billion. Since 2008, there have been significant changes in the rules and business practices of these two countries. As a result, China and New Zealand agreed to update their FTA in 2016. China and New Zealand signed an updated FTA on the $26^{\text {th }}$ of January, 2021. The upgraded FTA includes new regulations relating to e-commerce, competition policy, government procurement, and environmental and trade issues. Trade has always been an important pillar of New Zealand's economy and will continue to be an important enabler in the country's economic recovery post Covid-19. 


\section{References}

[1] Tekçe, M., \& Sevil, A., From Multilateralism to Bilateralism: The Evolution of Global Trade Policies. Marmara Üniversitesi Iktisadi Ve İdari Bilimler Dergisi, 24, 1, 2015, 105-123.

[2] Schott, P. K., Across-product versus Withinproduct Specialization in International Trade, The Quarterly Journal of Economics, 119, 2, 2004, pp. 647-678.

[3] Mashayekhi, M., Puri, L., \& Ito, T., Multilateralism and Regionalism: The New Interface, The New Interface, 2005, 1.

[4] Urata, S., (2002). Globalization and the Growth in Free Trade Agreements, Asia Pacific Review, 9, 1, 2002, pp. 20-32.

[5] Tekçe, M., \& Sevil, A., From Multilateralism to Bilateralism: The Evolution of Global Trade Policies, Marmara Üniversitesi İktisadi Ve İdari Bilimler Dergisi, 24, 1, 2015, 105-123 .

[6] Kayani, F. N., \& Kayani, U. N., Inward Foreign Direct Investment, Resident Patents, and Economic Growth: Cointegration, Error Correction Model, and Causality Analyses for China, Journal of Economic \& Management Perspectives, 11, 4, 2017, pp. 381-389.

[7] Aysan, A., Kayani, F., \& Kayani, U. N., The Chinese Inward RDI and Economic Prospects Amid COVID-19 Crisis, Pakistan Journal of Commerce and Social Sciences, 14, 4, 2020, pp. 1088-1105.

[8] Dean, M. K., \& Wignaraja, G., ASEAN 3 or ASEAN 6: Which way forward? Paper presented at the Conference on Multilateralising Regionalism Sponsored and Organized by WTO-HEI Co-Organized by the Centre for Economic Policy Research (CEPR). Date, 10-12.

[9] Lawrence, R. Z., China and the Multilateral Trading System, 2006, Working Papers.
[10] Zhang, Y., Zhang, G., \& Fung, H., The Prospects for China's Free Trade Agreements, Chinese Economy, 40, 2, 2007 , pp. 5-35

[11] Nguyen, D. K. L., \& Cao, T. H. V., Do Free Trade Agreements Generally and Individually Raise Foreign Direct Investment into Vietnam, Foreign Trade University, 2016, pp. 1-30.

[12] Cuong, H. C., Trang, T. T. N., \& Nga, D. T., Do Free Trade Agreements (FTAs) Really Increase Vietnam's Foreign Trade and Inward Foreign Direct Investment (FDI)? Journal of Economics, Management and Trade, 7(2), 2015, pp. 110-127.

[13] Jang, Y. J., The Impact of Bilateral Free Trade Agreements on Bilateral Foreign Direct Investment Among Developed Countries, The World Economy, 34, 9, 2011, pp. 1628-1651.

[14] Bae, C., \& Jang, Y. J., The Impact of Free Trade agreements on Foreign Direct Investment: The Case of Korea. Journal of East Asian Economic Integration, 17, 4, 2013, pp. 417-445.

[15] Jaumotte, F., Foreign Direct Investment and Regional Trade Agreements: The Market Size Effect Revisited, 2004, IMF Working Papers

[16] Bano, S., Trade Relations Between New Zealand and China: An Empirical Analysis in the Context of a Free Trade Agreement. Review of Economics \& Finance, 4, 2014, pp. 75-92.

[17] New Zealand Foreign Affairs and Trade, 2021, New Zealand Foreign Affairs and Trade, NZ Trade Policy.

\section{Creative Commons Attribution License 4.0 (Attribution 4.0 International, CC BY 4.0)}

This article is published under the terms of the Creative Commons Attribution License 4.0

https://creativecommons.org/licenses/by/4.0/deed.en US 